\title{
PENGARUH JENIS PUPUK CAIR DAN CARA PERLAKUAN TERHADAP PERTUMBUHAN STEK DAUN Begonia glabra Aubl.
}

\author{
I Putu Agus Hendra Wibawa", I Nyoman Lugrayasa
}

Pusat Penelitian Konservasi Tumbuhan dan Kebun Raya Kawasan Bali - LIPI

Candikuning, Baturiti, Tabanan Bali 82191

`Email korespondensi: agus.hen9@gmail.com

\begin{abstract}
One way to multiply Begonia is vegetatively using plant parts such as leaves, stems, branches or roots. The success of plant propagation is influenced by various factors, such as the type of cuttings and environmental factors such as temperature, humidity, light intensity and nutrients from the planting medium. The quality of the planting medium can be improved by adding fertilizers. This study aims to determine the effect of several types of liquid fertilizers, as well as their treatment methods on the growth of B. glabra leaf cuttings. The study was conducted using a randomized block design using several organic fertilizers including; Liquid Organic Fertilizer (POC), Super Nasa Fertilizer (SPR) and Green Star Fertilizer (GRS), by means of each treatment is soaked $(R)$ and watered $(S)$. The results showed that the POC/R treatment had a significant effect on the speed of shoot growth and plant height. POC/R treatment showed better growth, which was significantly different from other treatments. All fertilizer treatments affected the growth rate of shoots, but they had no significant effect on root length parameters. Different types of liquid fertilizers and their treatment methods give different results.

Keywords: Begonia glabra, liquid fertilizer, functional microbes
\end{abstract}

Abstrak. Salah satu cara perbanyakan Begonia adalah dengan cara vegetatif menggunakan bagian tanaman seperti daun, batang, cabang atau akar. Keberhasilan perbanyakan tanaman dipengaruhi oleh berbagai faktor, seperti jenis setek serta faktor lingkungan seperti temperatur, kelembaban, intensitas cahaya dan nutrisi dari media tanam. Kualitas media tanam dapat ditingkatkan dengan penambahan pupuk. Penelitian ini bertujuan untuk mengetahui pengaruh beberapa jenis pupuk cair, serta cara perlakuannya terhadap pertumbuhan stek daun $B$. glabra. Penelitian dilakukan dengan menggunakan rancangan acak kelompok dengan menggunakan beberapa pupuk organik diantaranya; Pupuk Organik Cair (POC), Pupuk Super Nasa (SPR) dan Pupuk Green Star (GRS), dengan cara perlakuan masing-masing adalah direndam (R) dan disiram (S). Hasil penelitian menunjukkan bahwa perlakuan POC/R berpengaruh nyata terhadap kecepatan tumbuhnya tunas dan tinggi tanaman. Perlakuan POC/R menunjukkan pertumbuhan yang lebih baik, yang berbeda nyata dengan perlakuan lainnya. Semua perlakuan pupuk berpengaruh terhadap kecepatan tumbuhnya tunas, namun tidak berpengaruh nyata terhadap parameter panjang akar. Perbedaan jenis pupuk cair dan cara perlakuannya memberikan hasil yang berbeda pula.

Kata kunci: Begonia glabra, pupuk cair, mikroba fungsional

\section{PENDAHULUAN}

Begonia (Begoniaceae) adalah salah satu marga besar dalam kelompok Angiospermae yang banyak ditemukan di hutan tropis (Tebbitt, 2005), dengan kekhasan karakter daun asimetris. Begonia juga dapat mudah dikenal dengan kombinasi karakter perawakan herba, dengan variasi bentuk, ukuran, corak dan warna daun yang menarik serta bunga yang berwarna-warni. Keistimewaan Begonia terutama terletak pada daunnya yang indah, berlekuk, berkerut, berumbai-rumbai atau berbulu menjadikannya sangat cocok dijadikan tanaman hias (Hartutiningsih, 2017).

Selain sebagai bahan obat, masyarakat di Bali (sekitar pinggir danau Buyan dan
Tamblingan) menggunakan jenis begonia dengan nama daerah bacem kebo sebagai sayur lalapan dan penghilang dahaga. Masyarakat Jawa Barat juga menggunakan salah satu jenis begonia (Begonia multangula dan Begonia robusta) sebagai pengganti asam dalam membuat sayur, sedangkan Di Cina Begonia fimbristipulata digunakan sebagai bahan campuran minuman segar serupa teh (Hartutiningsih \& Siregar, 2008).

Begonia glabra Aubl. adalah salah satu jenis Begonia yang diperjualbelikan dan digunakan sebagai tanaman hias. Untuk menjamin ketersediaan tanaman Begonia dalam jumlah yang cukup, diperlukan adanya upaya perbanyakan dan budidaya. 
Salah satu cara perbanyakan Begonia adalah dengan cara vegetatif menggunakan bagian tanaman seperti daun, batang, cabang atau akar. Moko (2004) menyatakan bahwa perbanyakan tanaman secara vegetatif memiliki beberapa keuntungan seperti, diperolehnya tanaman baru dengan sifat genetik yang sama dengan induknya, pertumbuhan yang seragam, serta dapat dilakukan secara konsisten dan berkelanjutan. Setek adalah salah satu teknik perbanyakan tanaman dengan menggunakan potongan tanaman yang ditumbuhkan menjadi individu baru (Sakai \& Subiakto, 2007). Wudianto (2004) menyatakan bahwa Begonia adalah salah satu jenis tumbuhan yang dapat diperbanyak dengan setek daun. Perbanyakan stek daun B. glabra sering terkendala oleh stek yang mudah busuk dan pertumbu tunas yang relatif lama.

Keberhasilan perbanyakan tanaman dipengaruhi oleh berbagai faktor, seperti jenis setek serta faktor lingkungan seperti temperatur, kelembaban, intensitas cahaya dan nutrisi dari media tanam. Kualitas media tanam dapat ditingkatkan dengan penambahan pupuk. Pupuk yang mengandung mikroba berguna dapat menghasilkan nutrisi dan hormon tumbuh yang dapat mendukung pertumbuhan tanaman. Mukhlis dan Lestari (2013) menyatakan bahwa mikroba dalam pupuk hayati dapat memproduksi hormon, terutama Indole Acetic Acid (IAA) yang dapat meningkatkan pertumbuhan tanaman. Penelitian ini bertujuan untuk mengetahui pengaruh beberapa jenis pupuk cair, serta cara perlakuannya terhadap pertumbuhan stek daun B. glabra.

\section{METODE}

\section{Lokasi penelitian}

Penelitian dilakuakan di rumah kaca Unit Pembibitan, Kebun Raya " Eka Karya" Bali dari bulan September - Nopember 2019. Tempet peneltian terletak pada ketinggian 1250-1450 dpl, dengan suhu disiang hari antara $17^{\circ}-25^{\circ} \mathrm{C}$ dan malam hari $10^{\circ}-15^{\circ} \mathrm{C}$, dan kelembaban $70-90 \%$.

\section{Rancangan percobaan}

Penelitian dilakukan dengan menggunakan rancangan acak kelompok. Setiap perlakuan menggunakan kompos sebagai media tumbuh. Percobaan terdiri atas 7 macam perlakuan yaitu:

POC/R: Pupuk Organik Cair/direndam selama 30 menit dalam larutan pupuk

SPR/R: Pupuk Super Nasa/direndam selama 30 menit dalam larutan pupuk

GRS/R: Pupuk Green Star/direndam selama 30 menit dalam larutan pupuk

POC/S: Pupuk Organik Cair/disiram dengan larutan pupuk

SPR/S: Pupuk Super Nasa/disiram dengan larutan pupuk

GRS/S: Pupuk Green Star/disiram dengan larutan pupuk

K: Kontrol (Langsung Ditanam Tanpa

Perlakuan)

Masing-masing perlakuan terdiri atas sepuluh ulangan. Pengamatan dilakukan seminggu sekali, pencatatan data dimulai sejak tunas pertama muncul. Parameter yang diamati antara lain : persentase tanaman yang hidup, jumlah tunas yang muncul, tinggi tanaman, dan panjang akar.

\section{Pupuk Organik Cair}

Isolat pupuk organik cair yang berbahan dasar mikroba fungsional diperoleh dari Pusat Penelitian Biologi-LIPI dan diperbanyak di Laboratorium Pemuliaan dan Potensi Tumbuhan, Kebun Raya "Eka Karya" Bali dengan menggunakan media gula aren, air kelapa dan molase (sesuai manual pembuatan pupuk cair). Biakan pupuk cair yang telah diinkubasi selama \pm 7 hari dipanen dan diencerkan menggunakan air bersih (bebas kaporit) sesuai dengan dosis perlakuan. Bahan dasar pupuk cair ini adalah mikroba fungsional tahan salinitas yang biasanya tumbuh pada lahan atau perairan dekat pantai. Mikroba jenis ini dapat hidup di lahan yang bersifat basa serta mengandung garam (Biswas et al. 2000). 


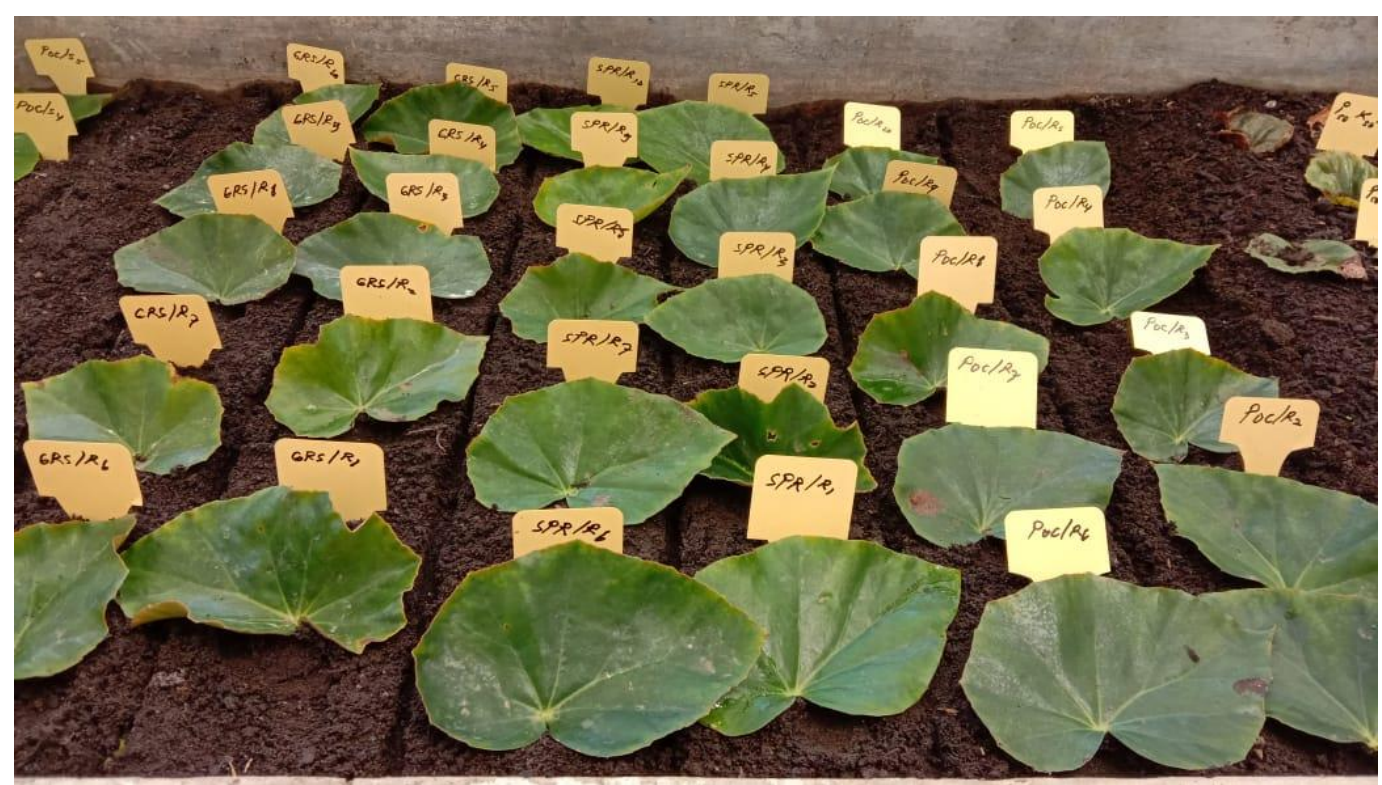

Gambar 1. Stek daun pada awal percobaan

\section{Pupuk Greenstar Nasa}

Pupuk Greenstar Nasa adalah pupuk organik yang merupakan produk dari PT. Nasa, diklaim merupakan pupuk organik dengan fungsi multiguna. Kandungan unsur hara macro maupun micro yang terkandung di dalamnya berperan dalam perkembangan tanaman. Fungsi utama pupuk ini adalah meningkatkan kuantitas dan kualitas produksi tanaman serta kelestarian lingkungan. Greenstar dapat diaplikasikan pada tanaman tahunan, tanaman semusim, tanaman hias maupun pembibitan. Greenstar juga mengandung hormon/zat pengatur tumbuh yang sangat dibutuhkan tanaman. Pupuk ini diklaim dapat mengurangi NPK sampai dengan $25 \%$.

\section{POP Supernasa}

POP Supernasa (Pupuk Organik Padat Supernasa) merupakan produk dari PT. Nasa, diklaim merupakan formula alami (organik) khusus yang berguna untuk memperbaiki sifat fisik tanah (menggemburkan), menyediakan semua unsur hara essensial bagi tanaman dan membantu meningkatkan perkembangan mikro-organisme tanah yang bermanfaat bagi tanaman. Supernasa dapat mengurangi penggunaan pupuk NPK berbahan kimia. Fungsi lain POP Supernasa adalah dapat meningkatkan produksi tanaman baik secara kualitas maupun kuantitas, melarutkan sisasisa bahan kimia yang berasal dari pupuk maupun pestisida dalam tanah, sehingga dapat dimanfaatkan kembali oleh tanaman, dapat memacu pertumbuhan tanaman, merangsang perkembangan bunga dan pembuahan serta mengurangi kerontokan bunga dan buah.

\section{Analisis data pengamatan}

Data pengamatan dicatat pada tabel, hasil pengamatan dianalisis dengan analisis varians $\alpha=5 \%$, apabila terdapat beda nyata, dilanjutkan dengan DMRT $\alpha=5 \%$. Analisis data dilakukan dengan program SAS/STAT Versi 9.0.

\section{HASIL DAN PEMBAHASAN}

Hasil penelitian menunjukkan bahwa perlakuan POC/R dapat mempercepat tumbuhnya tunas, lebih cepat dibandingkan dengan perlakuan lain. Tunas tercepat muncul pertama kali pada minggu keempat setelah perlakuan, sedangkan tunas yang paling lambat muncul pada minggu ketigabelas setelah perlakuan Semua perlakuan yang menggunakan Pupuk 
menunjukkan tumbuhnya tunas lebih cepat dibandingkan dengan Kontrol tanpa perlakuan. Pertumbuhan tunas tercepat berturut-turut ditunjukkan oleh POC/R; GRS/S; SPR/S; SPR/R; POC/S dan T (Gambar 2).

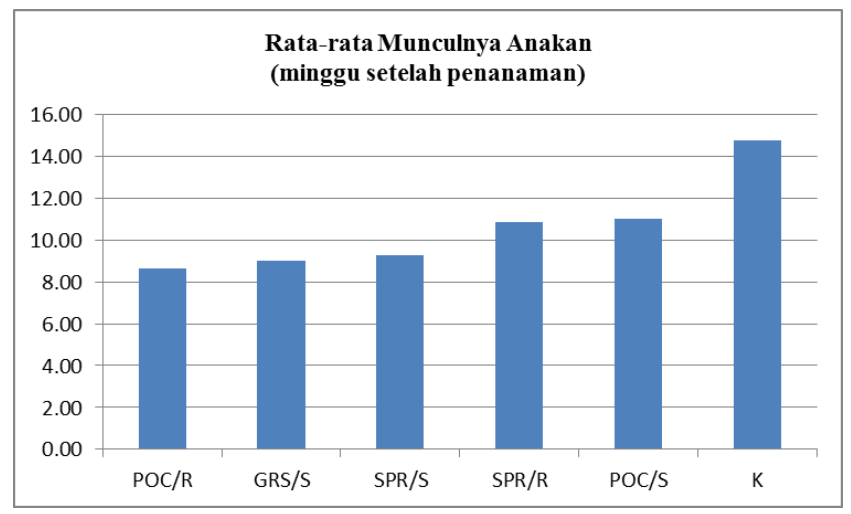

Gambar 2. Diagram batang rata-rata munculnya anakan

Hasil penelitian juga menunjukkan bahwa, pada parameter jumlah tanaman yang hidup, persentase tertinggi ditunjukkan oleh perlakuan SPR/S. Sedangkan persentase terendah ditunjukkan oleh perlakuan GRS/R, hasil ini bahkan lebih rendah dari Kontrol tanpa perlakuan. Hal ini kemungkinan terjadi karena Pupuk GRS mengandung mikroorganisme hidup yang bersifat sebagai pengurai atau perombak, sehingga perlakuan perendaman dapat membuat stek tanaman menjadi rusak atau mati (Gambar 3).

Pada parameter jumlah tunas, rata-rata jumlah tunas tertinggi ditunjukkan oleh perlakuan $\mathrm{POC} / \mathrm{R}$ diikuti oleh perlakuan SPR/S. Sedangkan pada perlakuan lain tidak menunjukkan perbedaan yang signifikan (Gambar 4).

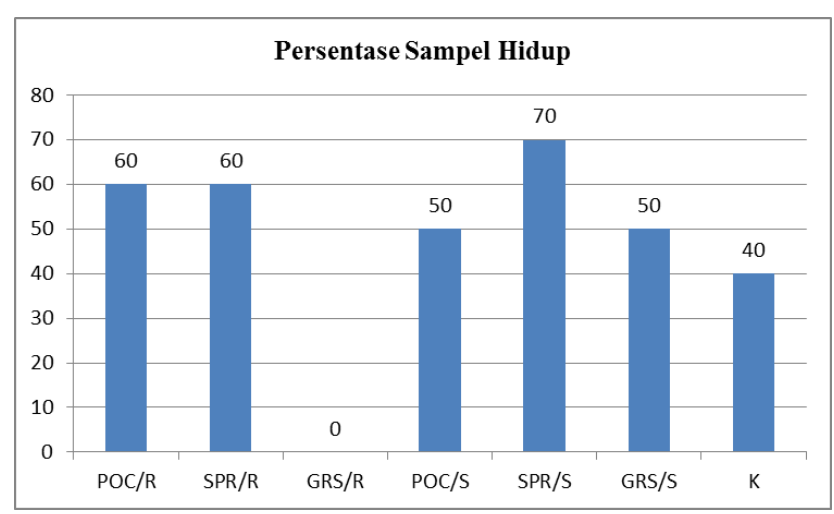

Gambar 3. Diagram batang persentase stek yang hidup pada masing-masing perlakuan

Perlakuan pupuk tidak berpengaruh nyata terhadap parameter panjang akar (Lampiran 1.). Perlakuan POC/R berpengaruh terhadap tinggi tanaman dan jumlah tanaman yang tumbuh per periode pengamatan. Perlakuan POC/R menunjukkan pertumbuhan yang lebih baik, dibandingkan dengan perlakuan lainnya (Gambar 5 \& 6). 


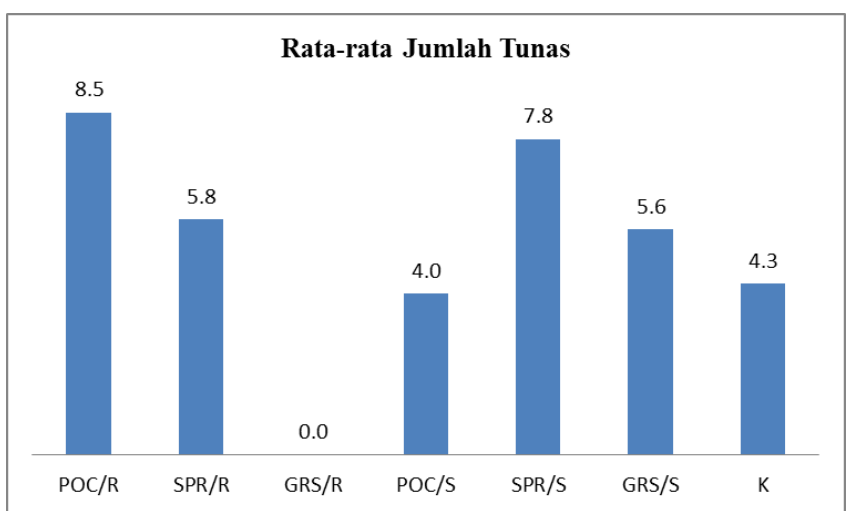

Gambar 4. Diagram batang persentase rata-rata jumlah tunas

Pertumbuhan tanaman yang lebih baik pada perlakuan POC kemungkinan disebabkan oleh kandungan hormon IAA yang dihasilkan oleh mikroba yang terdapat pada pupuk cair. Wibawa \& Lugrayasa (2019) menyatakan bahwa pemberian Pupuk Organik Cair pada stek batang Begonia menunjukkan pertumbuhan yang jauh lebih baik dibandingkan dengan tanpa perlakuan. Menurut Mahfudz (2003) adanya hormon tumbuh pada stek tanaman dapat meningkatkan laju pertumbuhannya. Moko (2004) menyatakan bahwa hormon tumbuh adalah senyawa kimia bukan nutrisi yang dalam konsentrasi rendah dapat memacu pertumbuhan tanaman, seperti pembentukan akar, pertumbuhan batang dan tunas. Adinugraha \& Setiadi (2003) menyatakan bahwa keberhasilan pertumbuhan setek dipengaruhi oleh kecepatan terbentuknya akar sehingga proses fisiologis tanaman dapat berlangsung dengan sempurna

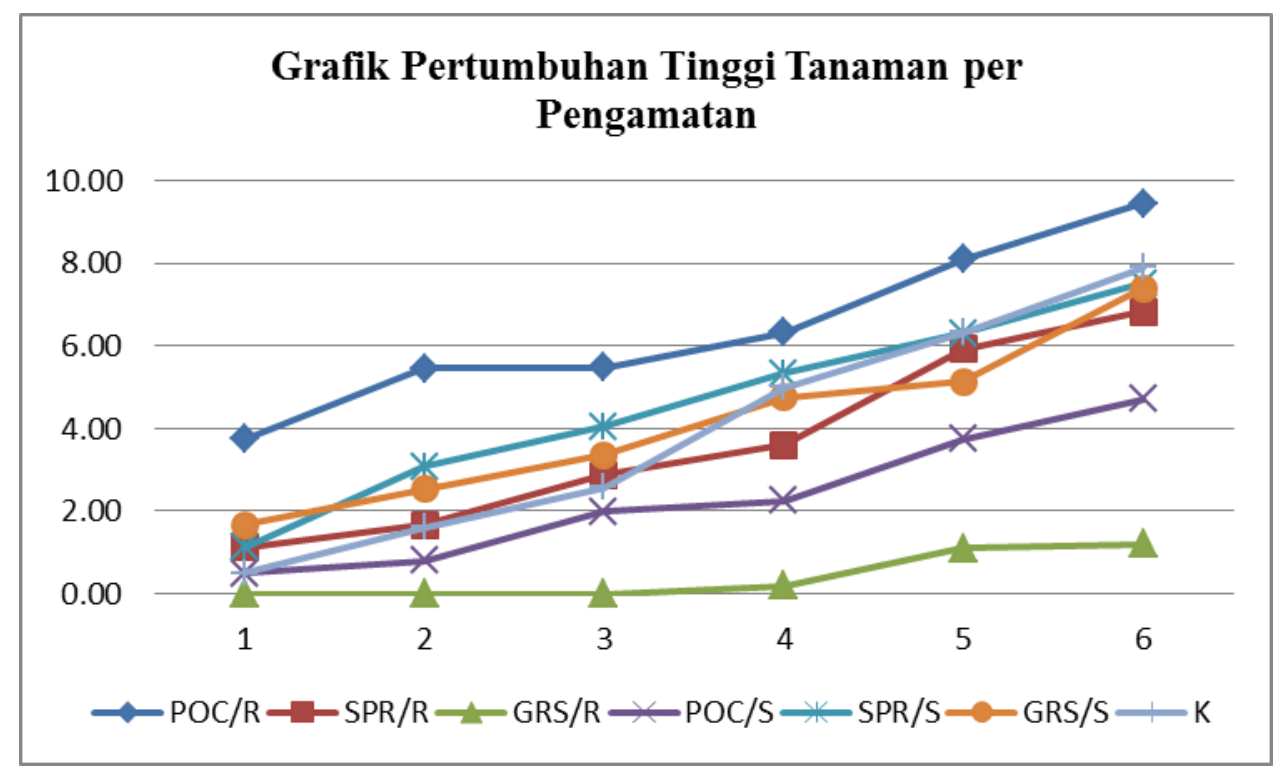

Gambar 5. Matrik pertumbuhan tinggi tanaman setiap kali pengamatan.

Mikroba fungsional dapat memproduksi hormon tumbuh yang berperan dalam membantu pertumbuhan tanaman, serta dapat menyediakan unsur hara seperti nitrogen dan fosfat (Widawati, 2015). Mikroba fungsional berperan sebagai biofertilizer yang dapat memperbaiki kualitas tanah secara biologis (Wijebandara et al. 2009). Banig et al. (2008) menyatakan bahwa mikroba fungsional berperan penting dalam siklus biogeokimia seperti siklus karbon, sulfur, nitrogen dan fosfor. 


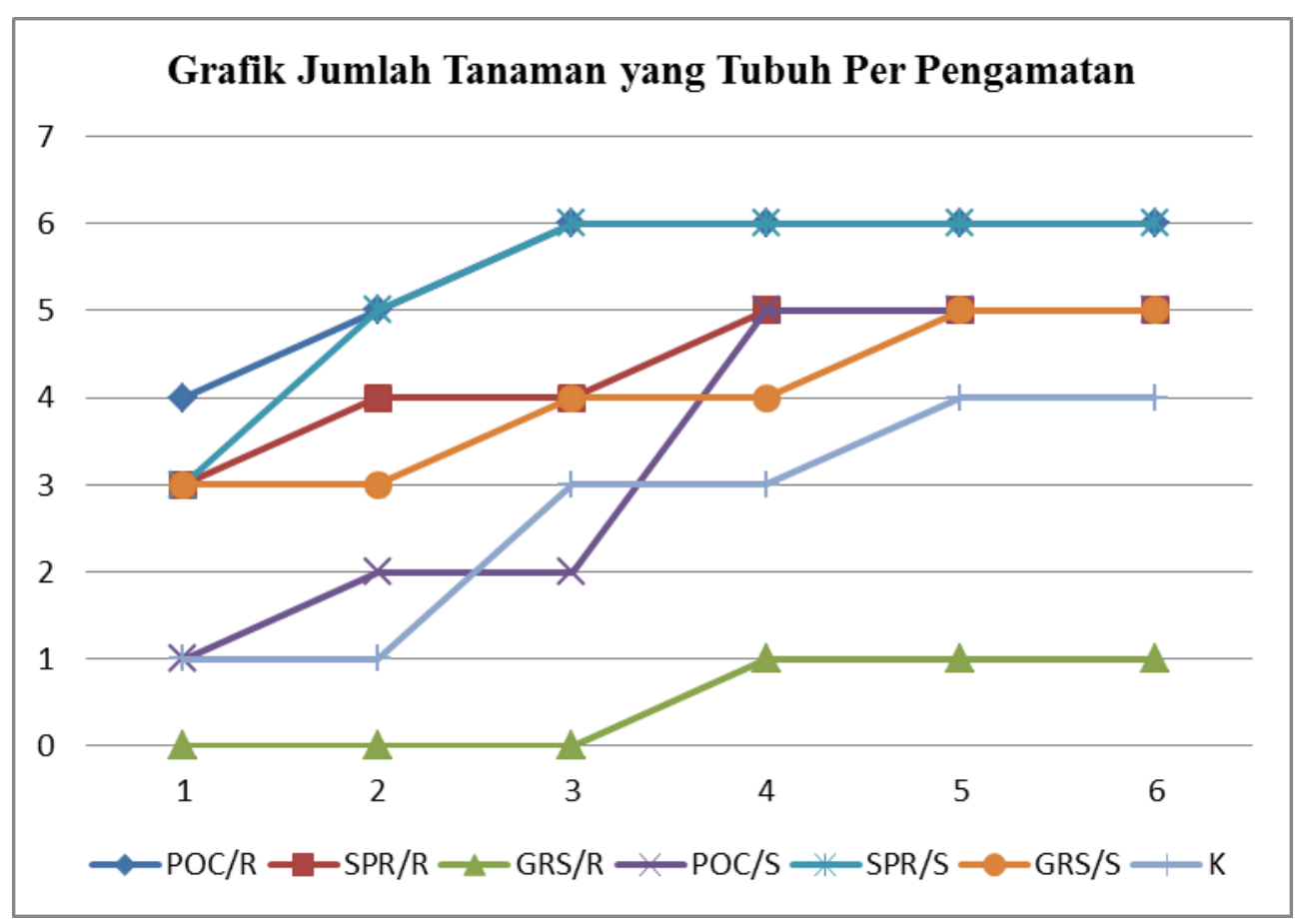

Gambar 6. Matrik pertumbuhan tanaman setiap kali pengamatan.

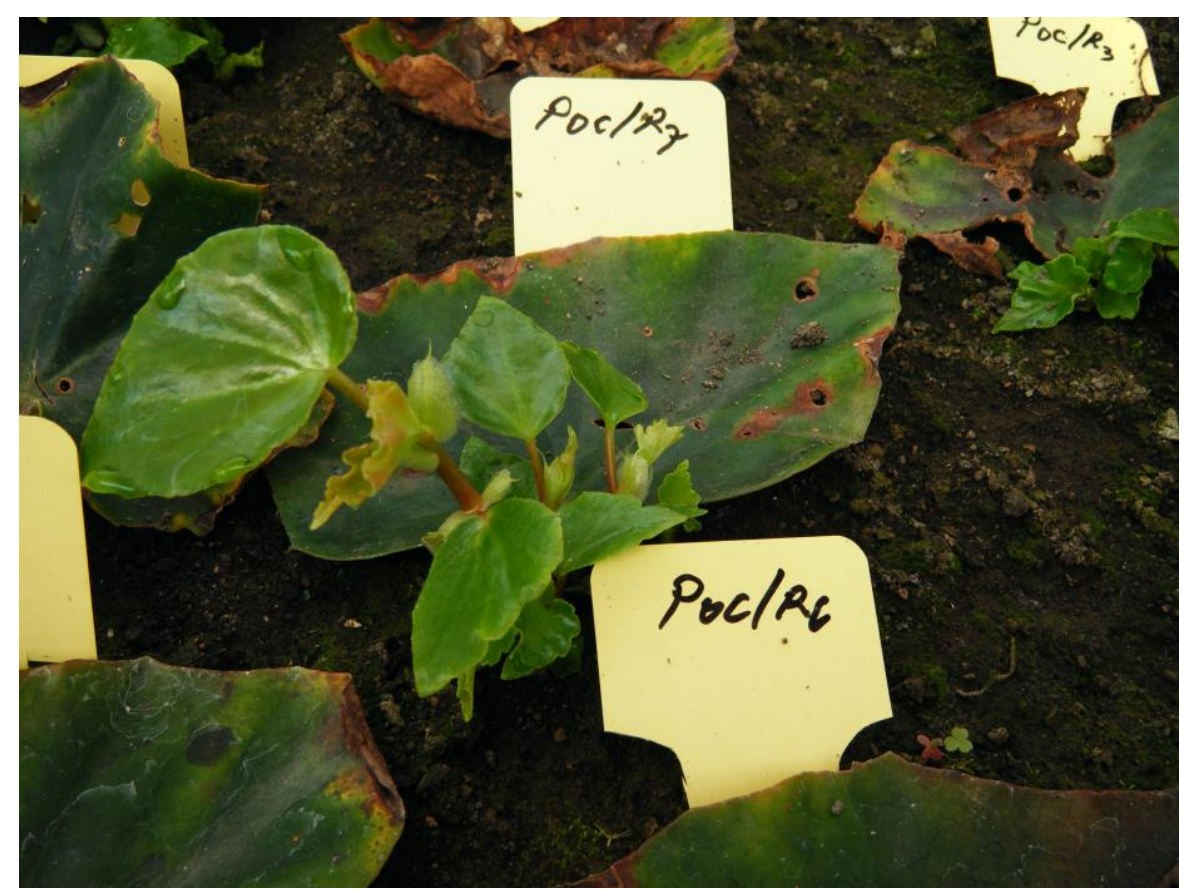

Gambar 7. Pertumbuhan tunas dari stek daun umur 8 minggu

Kelompok mikroba fungsional, mampu memperbaiki kesuburan tanah karena bersifat memupuk serta mampu menghasilkan hormon tumbuh yang dapat memacu pertumbuhan tanaman. Nurosid et al. (2008) menyatakan bahwa bakteri dari jenis Azospirillum memiliki kemampuan sebagai penambat Nitrogen, mampu merombak bahan organik seperti selulosa, amilosa, lemak serta protein yang terkandung dalam tanah. Widawati (2014) menyatakan bahwa bakteri tersebut juga 
mampu memproduksi hormon pertumbuhan seperti IAA serta melarutkan P terikat pada Ca3(PO4)2. Mikroba fungsional dapat menghambat pathogen secara tidak langsung melalui pembentukan senyawa yang bersifat antibiotik (Saraswati \& Sumarno 2008).

Menurut Widawati (2014) bakteri pelarut fosfat dari genus Pseudomonas, Bacillus, dan Cerratia adalah bakteri yang dapat memproduksi hormon IAA. Bakteri pelarut fosfat adalah satu-satunya kelompok bakteri yang dapat melarutkan $\mathrm{P}$ yang terikat dalam oksida besi (Fe-P) dan oksida almunium (Al-P) dengan memproduksi enzim fosfatase (Hartono, 2000). Widawati dan Muharam (2012) menyatakan bahwa bakteri pelarut fosfat adalah bakteri yang mampu hidup dalam lingkungan dengan salinitas tinggi.

\section{SIMPULAN}

Perlakuan POC/R menunjukkan pertumbuhan yang lebih baik pada parameter kecepatan tumbuhnya tunas dan tinggi tanaman. Semua perlakuan pupuk berpengaruh terhadap kecepatan tumbuhnya tunas, namun tidak berpengaruh terhadap parameter panjang akar. Perbedaan jenis pupuk cair dan cara perlakuannya memberikan hasil yang berbeda pula.

\section{DAFTAR PUSTAKA}

Adinugraha, H.A. dan D. Setiadi. 2003. Pengaruh Pupuk Organik Cair SNN (Super Natural Nutrition) dan Lamanya Perendaman terhadap Pertumbuhan Stek Pucuk Eucalyptus pellita di Persemaian. Jurnal Pemuliaan Tanaman Hutan Vol.1 (2) : 4954.

Banig, A.E., Aly, E.A., Khaled, A.A., Amel, K.A. 2008. Isolation, characterization and application of bacterial population from agricultural soil at Sohag Province, Egypt. Malaysian J Microbiol 4 (2): 42-50.

Biswas, J.C., Ladha, J.K., Dazzo, F.B. 2000. Rhizobial inoculation improves nutrient uptake and growth of lowland rice. Soil Sci SocAm J 64: 1644-1650

Hartono, A. 2000. Pengaruh pupuk fosfor, bahan organik, dan kapur terhadap pertumbuhan jerapan $\mathrm{P}$ pada tanah masam latosol Darmaga. Gakuryoku 6 (1): 73-78.

Hartutiningsih dan M. Siregar. 2008. Mengenal dan Merawat Begonia. PT. Agromedia Pustaka. Jakarta.

Hartutiningsih, M.S dan Siregar, M. 2013. Seratus Jenis Begonia Eksotik Kebun Raya Siap Bersaing Mendukung Bisnis Florikultura Di Masa Yang Akan Datang. Prosiding Seminar Inovasi Florikultura Nasional. Balai Penelitian Tanaman Hias. Pusat Penelitian dan PengembanganTanaman Holtikulturaa. Kementrian Kehutanan.

Hartutiningsih, 2017. The Conservation of Native, Lowland Indonesian Begonia species (Begoniaceae) in Bogor Botanic Gardens. Biodiversitas 18(1): 326-333.

Mahfudz, Fauzi M.A. dan Hamdan. 2003. Pengaruh Media dan Dosis Rootone-F terhadap Keberhasilan Stek Pucuk Pulai (Alstonia scholaris (L).R.Br.). Jurnal Pemuliaan Tanaman Hutan Vol.1 (2) : 1 9. Pusat Penelitian dan Pengembangan Bioteknologi dan Pemuliaan Tanaman Hutan. Yogyakarta.

Moko, H. 2004. Teknik Perbanyakan Tanaman Hutan Secara Vegetatif. Informasi Teknis Vol.2 (1) : 120. Puslitbang Bioteknologi dan Pemuliaan Tanaman Hutan. Yogyakarta.

Mukhlis, Y. Lestari. 2013. Effect of biofertilizer "M-Star" on land productivity and growth of sweet corn in acid sulphate soil of swampland. J. Agriv. 35(3): 242-248.

Nurosid, Oedjijono, Lestari P. 2008. Kemampuan Azospirillum sp. JG3 dalam Menghasilkan Lipase pada Medium Campuran Dedak dan 
Onggok dengan Waktu Inkubasi berbeda, Universitas Soedirman, Purwokerto.

Sakai, C. dan A. Subiakto. 2007. Pedoman Pembuatan Setek Jenis-jenis Dipterocarpa dengan Koffco System. Badan Litbang Kehutanan, Komatsu, \& Jica. Bogor.

Saraswati R. dan Sumarsono. 2008. Pemanfaatan mikroba penyubur tanah sebagai komponen teknologi pertanian. Iptek Tanaman Pangan 3(1): $\mathrm{xx}$.

Tebbitt, M.C. 2005. Begonias: Cultivation, Identification and Natural History. Portland: Timber Press, Inc.

Tiwari, S., Singh, P., Tiwari, R., Meena, K.K., Yandigeri, M., Singh, D.P, Arora, D.K. 2011. Salt-tolerant rhizobacteria-mediated induced tolerance in wheat (Triticum aestivum) and chemical diversity in rhizosphere enhance plant growth. Biol Fert Soils 47: 907-916.

Wibawa I.P.A.H. \& I.N. Lugrayasa. 2019. Pengaruh Konsentrasi Pupuk Cair (Mikroba Fungsional Tahan Salin) Terhadap Perkembangan Stek Daun Begonia rex "Silver Circle". Jurnal Agroekoteknologi Tropika (Journal of Tropical Agroecotechnology). Vol.8, No.2.
Widawati S. dan Muharam A. 2012. Uji laboratorium Azospirillum sp. yang diisolasi dari beberapa ekosistem. J Hortikultura 22 (3): 258-267

Widawati S. 2014. The effect of salinity to activity and effectivity phosphate solubilizing bacteria on growth and production of paddy. In: Pratiwi R, Nurlaely S, Maryani, Retnoaji B, Nuringtyas TR, Susandarini R (eds). Advances in Biological Science: Biological Approach for Sustainable Development of Tropical Biodiversitas for Human Prosperity. Proceeding of the International Conference on Biological Science Faculty of Biology. Gadjah Mada University, Yogyakarta.

Widawati, S. 2015. Peran bakteri fungsional tahan salin (PGPR) pada pertumbuhan padi di tanah berpasir salin. Prosiding Sem Nas Masy Biodiv Indon Volume 1, Nomor 8. Halaman: 1856-1860.

Wijebandara, D.M., Iranie, D., Dasog, G.S., Patil, P.L., Hebbar, M. 2009. Response of rice to nutrients and biofertilizers under conventional and system of rice intensification methods of cultivation in Tungabhadra command of Karnataka. Karnataka J Agric Sci22 (4): 741-750.

Wudianto, R. 2004. Membuat Setek, Cangkok dan Okulasi. Penebar Swadaya. Jakarta. 